\title{
Pengembangan dan Sosialisasi Game Edukasi Matematika Berbasis Android "GESIT" sebagai Alternatif Media Pembelajaran pada Masa Pandemi COVID-19
}

\author{
Robiatul Adawiyah ${ }^{*}$, Lela Nur Safrida ${ }^{2}$ \\ Universitas Jember, Jl. Kalimantan II/24, Kampus Bumi Tegal Boto, Jember, Jawa Timur ${ }^{1,2}$ \\ Email: robiatul@unej.ac.id ${ }^{1 *}$
}

\begin{abstract}
ABSTRAK
Di tengah mewabahnya Virus Corona (COVID-19), kesadaran pendidik akan pentingnya pengetahuan mengenai penggunaan teknologi khususnya media pembelajaran interaktif online untuk menunjang pembelajaran semakin meningkat. Kesadaran tersebut selaras dengan pendidikan yang kini tengah dicanangkan oleh Menteri Pendidikan bahwasanya pembelajaran bukan hanya bisa dilakukan di dalam kelas, tapi bisa dilaksanakan dimanapun dengan media serta sumber apapun. Oleh karena itu, pembelajaran online memberikan tantangan tersendiri bagi guru dalam merancang pembelajaran yang menarik dan menyenangkan meski secara daring. Kegiatan pengabdian ini bertujuan untuk mengembangkan dan mensosialisasikan media pembelajaran alternatif pada masa pandemi COVID-19 berupa game edukasi berbasis android. Adapun instrumen yang digunakan yaitu lembar validasi dan angket respon. Berdasarkan hasil validasi dan uji coba menunjukkan bahwa GESIT memenuhi kriteria valid, praktis, dan efektif untuk digunakan. GESIT membantu siswa untuk belajar materi pola bilangan secara mandiri dan menyenangkan. Adanya respon positif dari siswa dan guru menunjukkan bahwa GESIT dapat dimanfaatkan dalam pembelajaran tanpa terikat jarak dan waktu sehingga lebih efisien. Selain itu, pengembangan game edukasi telah memberikan referensi dan motivasi bagi guru untuk mengembangkan game serupa.
\end{abstract}

Kata kunci: GESIT; COVID-19; Game Edukasi; Android

\begin{abstract}
In the midst of the Coronavirus (COVID-19) outbreak, educators' awareness of the importance of knowledge about the use of technology, especially online interactive learning media to support learning is increasing. The awareness is in line with the education that is now being proclaimed by the Minister of Education that learning can not only be done in the classroom, but can be carried out anywhere with any media and sources. Therefore, online learning presents its own challenges for teachers in designing interesting and fun learning even online. This devotional activity aims to develop and socialize alternative learning media during the COVID-19 pandemic in the form of android-based educational games. The instruments used are validation sheets and response questionnaires. Based on validation and trial results show that GESIT meets valid, practical, and effective criteria for use. GESIT helps students to learn number pattern materials independently and pleasantly. The positive response from students and teachers shows that GESIT can be utilized in learning without being tied to distance and time so that it is more efficient. In addition, the development of educational games has provided references and motivation for teachers to develop similar games.
\end{abstract}

Keywords: GESIT; COVID-19; Education Game; Android 


\section{PENDAHULUAN}

Di tengah mewabahnya virus Corona (COVID-19), berbagai kebijakan dilakukan oleh pemerintah Indonesia guna menekan penyebaran virus melalui social distancing. Kebijakan tersebut juga terintegrasi dalam dunia Pendidikan melalui Surat Edaran Kementerian Pendidikan dan Kebudayaan (Kemendikbud) Direktorat Pendidikan Tinggi No. 1 Tahun 2020 dimana penyelenggaran pembelajaran dilakukan jarak jauh dan dilakukan dari rumah. Selanjutnya pembelajaran jarak jauh dikenal menjadi pembelajaran online (daring). Hal tersebut didukung oleh hasil penelitian Handarini dan Wulandari (2020) yang menyimpulkan bahwa pembelajaran daring telah menjadi salah satu solusi dalam menekan penyebaran virus COVID-19.

Pembelajaran online telah semakin meningkatkan kesadaran masyarakat akan pentingnya pengetahuan mengenai penggunaan teknologi khususnya media pembelajaran interaktif online untuk menunjang pembelajaran (Martins, 2015). Pembelajaran secara daring menuntut pendidik dan siswa untuk memanfaatkan teknologi yang telah berkembang pesat setelah adanya revolusi industry 4.0. yang terfokus pada IoT (Internet of Thing) atau IoE (Internet of Everything). Oleh karena itu, pembelajaran daring memerlukan sarana dan prasarana yang memadai (Handarini dan Wulandari, 2010). Namun, salah satu tantangan bagi seorang pendidik adalah bagaimana menciptakan suatu pembelajaran online yang tidak monoton dan menarik minat dari siswa serta meningkatkan semangat belajar siswa (Hasanah, 2020).

Berdasarkan fakta yang ada di lapangan, siswa lebih suka bermain game yang bersifat dinamis dibanding dengan mendengarkan penjelasan guru melalui aplikasi webmeeting atau hanya mengerjakan tugas-tugas semata yang cenderung monoton dan membosankan. Adanya fakta tersebut membuat para tenaga pengajar untuk mencari alternatif komponen belajar, salah satu dengan mengembangkan media pembelajaran yang mampu meningkatkan motivasi belajar siswa (Arda dkk, 2015). Media menyediakan banyak manfaat dalam pembelajaran diantaranya membuat suasana belajar lebih menarik, efisien dalam penggunaan waktu dan usaha, mengimprovisasi tujuan pembelajaran yang dapat dicapai siswa, serta dapat membantu proses pembelajaran dapat dilakukan dimanapun dan kapanpun (Karo-karo dan Rohani, 2018; Nurrita, 2018). Salah satu media yang dapat dikembangkan yaitu education game untuk mendukung kegiatan pembelajaran online. Salah satu software pengembang media berbasis teknologi yang dapat digunakan dalam pembelajaran matematika yaitu game berbasis android dengan memanfaatkan Software Gamesalad. 
Gamesalad merupakan salah satu perangkat lunak pengembang permainan dua dimensi. Pengembangan game edukasi dilakukan dengan menyisipkan materi dalam sebuah game agar proses memahami materi tersebut lebih mudah dan menyenangkan. Selain itu, adanya animasi menambah daya tarik dan motivasi untuk belajar Matematika. Smartphone yang memiliki banyak pengguna yaitu android (Pratama dan Haryanto, 2017). Oleh karena itu, semua vendor smartphone berlomba-lomba untuk memproduksi android dengan berbagai keunggulan.

Matematika menjadi salah satu mata pelajaran yang dianggap sulit oleh siswa yang mengaitkan pengetahuan tentang penalaran logik dan bilangan. Oleh karena itu, belajar Matematika menuntut siswa untuk berpikir logis dengan memeprhatikan pola dan aturan yang telah baku. Pembelajaran matematika hendaknya dirancangan untuk mengembangkan dan meningkatkan kreativitas siswa serta kemampuan berpikir matematis. Namun, saat ini siswa belum mampu mengembangkan daya nalarnya secara optimal sehingga terkadang masih kesulitan memahami konsep Matematika. Selain itu, hasil studi juga menunjukkan bahwa minat siswa dalam pembelajaran matematika rendah sehingga berdampak pada rendahnya hasil belajar matematika siswa (Firmansyah, 2015). Oleh karena itu, perlu dilakukan improvisasi terhadap proses pembelajaran untuk meningkatkan minat siswa, terutama dalam masa pandemi COVID-19, kami mengusulkan untuk membuat suatu game edukasi matematika yang menarik dan bisa menolong para guru untuk mencapai tujuan dari pembelajaran. Adapun kelebihan penggunaan game android sebagai media pembelajaran yaitu menciptakan situasi belajar yang menyenangkan, memberi pemahaman materi lebih mudah dan menambah pengalaman belajar siswa serta memerlukan waktu yang lebih singkat bagi guru dalam menyampaikan suatu materi. Tujuan kegiatan pengabdian ini adalah memberikan media alternatif bagi guru untuk membantu siswa memahami materi lebih mudah khususnya materi mengenai pola bilangan melalui pemanfaatan game edukasi matematika berbasis android.

\section{METODE}

Kegiatan pengabdian kepada masyarakat berupa Pendidikan Masyarakat. Pelaksanaan kegiatan pengabdian kepada masyarakat terdiri dari empat tahap pengembangan 4D diantaranya tahap pendefinisian, tahap perancangan, tahap pengembangan, dan tahap penyebaran.

1. Tahap pendefinisian dilakukan menganalisis tujuan dan memperhatikan batasan materi yang bertujuan untuk mendefinisikan kebutuhan dalam pembelajaran. 
2. Tahap perancangan terdiri dari kegiatan pemilihan media, pemilihan format, rancangan awal media, dan penyusunan soal untuk dicantumkan pada game android.

3. Tahap pengembangan bertujuan untuk mengembangkan game edukasi berbasis android yang selanjutnya diberi penilaian oleh ahli.

4. Tahap penyebaran dan sosialisasi dalam pengabdian ini dilakukan di beberapa sekolah di Kabupaten Jember dan publish link serta extract dari produk di media sosial dan web.

Pelaksanaan pengabdian kepada masyarakat ini dilakukan pada rentang waktu dua bulan yaitu Oktober-November 2020. Pelaksanaan pengabdian dilakukan di beberapa sekolah mitra di Kabupaten Jember yaitu SMP Negeri 1 Rambipuji Jember, SMP Mitra Jember, dan SMP Negeri 7 Jember. Adapun peserta atau sasaran kegiatan pengabdian yaitu guru sekolah. Peserta di SMP Negeri 1 Rambipuji Jember sejumlah 20 orang, peserta di SMP Negeri 7 Jember sejumlah 25 orang dan peserta di SMP Mitra Jember sejumlah 15 orang. Kegiatan pengabdian dilakukan secara offline dengan mematuhi protokol kesehatan. Metode penyampaian melalui ceramah, diskusi, dan praktik.

Adapun metode pengumpulan data yang digunakan yaitu metode angket dan metode dokumentasi. Instrumen yang digunakan dalam kegiatan pengabdian ini yaitu (1) lembar validasi dan (2) angket respon. Analisis data dilakukan secara kuantitatif dengan menganalisis hasil validasi dan angket respon peserta.

\section{HASIL, PEMBAHASAN, DAN DAMPAK}

Penentuan media dilakukan berdasarkan hasil analisis awal-akhir. Penulis menentukan untuk mengembangkan game edukasi matematika pada Android karena game memberikan ketertarikan lebih pada siswa sehingga diharapkan siswa mampu meningkatkan kemampuan penalaran matematis dengan pembelajaran matematika yang lebih menarik. Pengembangan game edukasi "GESIT" pada Android dilakukan peneliti dengan menggunakan software Unity secara mandiri. Peneliti menyusun konsep game dengan menyesuaikan indikator penalaran matematis siswa pada topik pola bilangan, game ini juga akan lebih difokuskan kepada siswa yang kurang memiliki ketertarikan pada materi pola bilangan. Diharapkan dengan adanya game ini kemampuan penalaran matematis pada topik pola bilangan dapat meningkat. GESIT terdiri dari 6 stage permainan dimana setiap stage akan menyesuaikan setiap indikator. Pemilihan game edukasi matematika pada Android ini memanfaatkan ketersediaan gadget yang dimiliki siswa untuk digunakan secara maksimal sebagai media untuk belajar. 
Setelah dihasilkan prototipe GESIT, dilanjutkan dengan validasi. Validasi dilakukan pada dua orang ahli di bidang pendidikan dan media pembelajaran. Hasil rekapitulasi validasi disajikan pada Tabel 1 .

Tabel 1. Rekapitulasi Hasil Validasi

\begin{tabular}{|c|c|c|c|c|}
\hline \multirow{2}{*}{ No } & \multirow{2}{*}{ Aspek Penilaian } & \multicolumn{2}{|c|}{ Hasil Penilaian } & \multirow{2}{*}{ Rerata } \\
\hline & & Ahli 1 & Ahli 2 & \\
\hline 1 & Validasi Isi & 3,5 & 3,6 & 3,55 \\
\hline 2 & Validasi Konstruksi & 3,6 & 3,5 & 3,55 \\
\hline 3 & Bahasa & 3,4 & 3,5 & 3,45 \\
\hline 4 & Tampilan & 3,5 & 3,5 & 3,5 \\
\hline 5 & Petunjuk & 3,6 & 3,6 & 3,6 \\
\hline & Rata-rata & & & 3,53 \\
\hline
\end{tabular}

Hasil validasi memberikan skor rata-rata 3,53 yang menunjukkan bahwa media GESIT telah valid dan dapat diujicobakan.

Selanjutnya GESIT diujicobakan pada beberapa siswa SMP dengan memainkannya. Berdasarkan hasil uji coba, dapat disimpulkan bahwa media GESIT dapat dimainkan dengan mudah karena dilengkapi dengan petunjuk permainan. Oleh karena itu, media GESIT dapat dikatakan praktis. Tahap berikutnya yaitu desiminasi. Desiminasi dilakukan dengan mensosialisasikan ke beberapa sekolah dan diunggah di google playstore agar dapat digunakan secara luas khususnya oleh siswa.

Game edukasi berbasis Android dikembangkan dalam bentuk format .apk, dimana pemain dapat mendownloaddi Google Playstore sehingga siswa dapat mengakses dan meng-install game dengan mudah, tampilan game dapat dilihat pada Gambar 1 berikut.

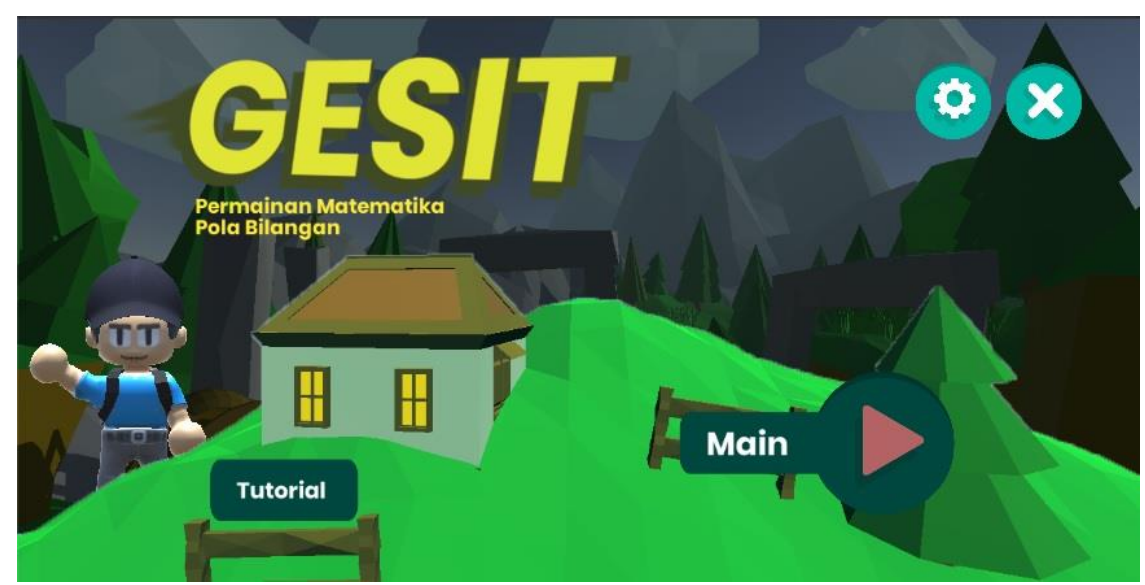

Gambar 1. Tampilan GESIT di HP Android

Konten yang disajikan dalam media pembelajaran game edukasi adalah:

1. GESIT (Game Edukasi Matematika) pemain terus bergerak maju dan dapat bergerak ke samping kanan dan kiri untuk mencari dan mengumpulkan koin. 
2. Terdapat 6 buah level dalam permainan ini yaitu sebagai berikut
a. Level 1: pola bilangan genap
b. Level 2: pola bilangan ganjil
c. Level 3: pola bilangan segitiga
d. Level 4: pola bilangan persegi
e. Level 5: pola bilangan persegi panjang
f. Level 6: pola bilangan beda 3

Pada setiap level 1 pemain akan mencari koin, pemain akan mencari nilai pola bilangan yang nilainya sesuai dengan gambar. Sebelumnya pada stage 1 pemain juga akan diarahkan menuju stage 0 untuk mengikuti arahan atau tutorial untuk memahami konsep bermain GESIT. Setiap pemain akan menduga beberapa bilangan yang akan muncul selanjutnya, dengan mencari nilai pola bilangan pada koin. Kesulitan tiap level makin meningkat, baik itu misi yang harus diselesaikan, kecepatan pemain dan waktu yang diberikan.

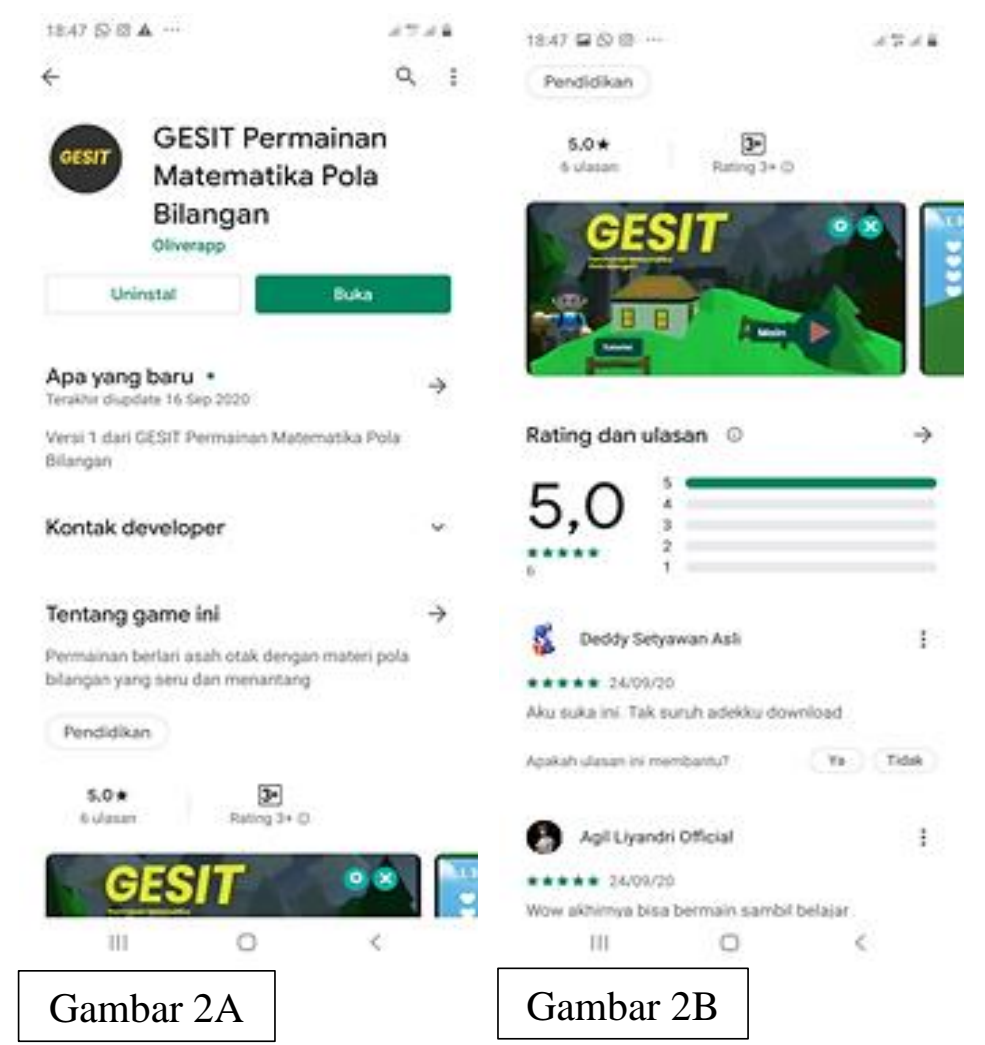

Gambar 2A. Tampilan GESIT di Playstore dan Gambar 2B. ulasan mengenai GESIT oleh pengguna

Penyebaran produk ini dilakukan secara resmi melalui penyedia layanan aplikasi dari Google yakni Google Playstore. Media ini digunakan karena Google Playstore telah menjamin segala hal terkait dengan game baik lisensi, kecocokan dengan perangkat yang 
ada, keamanan, ijin akses, dan lain sebagainya. Selain itu Google Playstore dapat diakses oleh semua orang dimana saja dan kapan saja melalui perangkat Android mereka. Alamat langsung untuk menuju ke dalam aplikasi ini dapat diakses dan didownload secara penuh melalui link berikut: https://play.google.com/store/apps/details?id=com.FKIPUnej.GESIT.

Diseminasi dilakukan melalui media sosial dan sosialisasi secara langsung di beberapa sekolah di lingkungan Kabupaten Jember. Berikut adalah foto-foto kegiatan sosialisasi yang telah dilaksanakan oleh penulis.

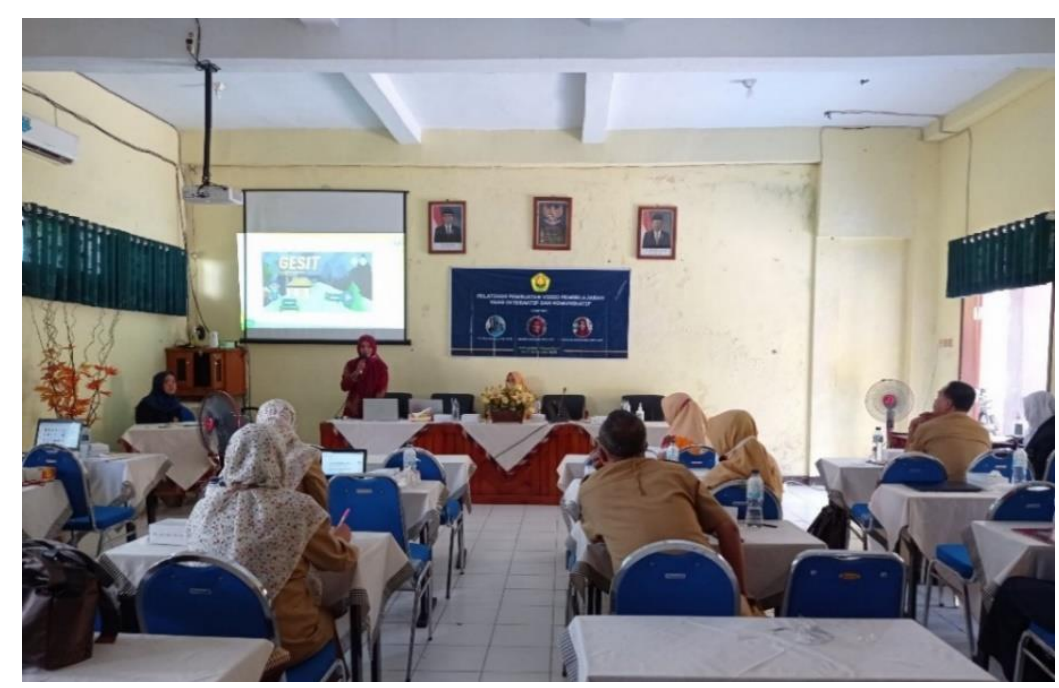

Gambar 3. Kegiatan pengabdian kepada masayarakat di SMP Negeri 1 Rambipuji

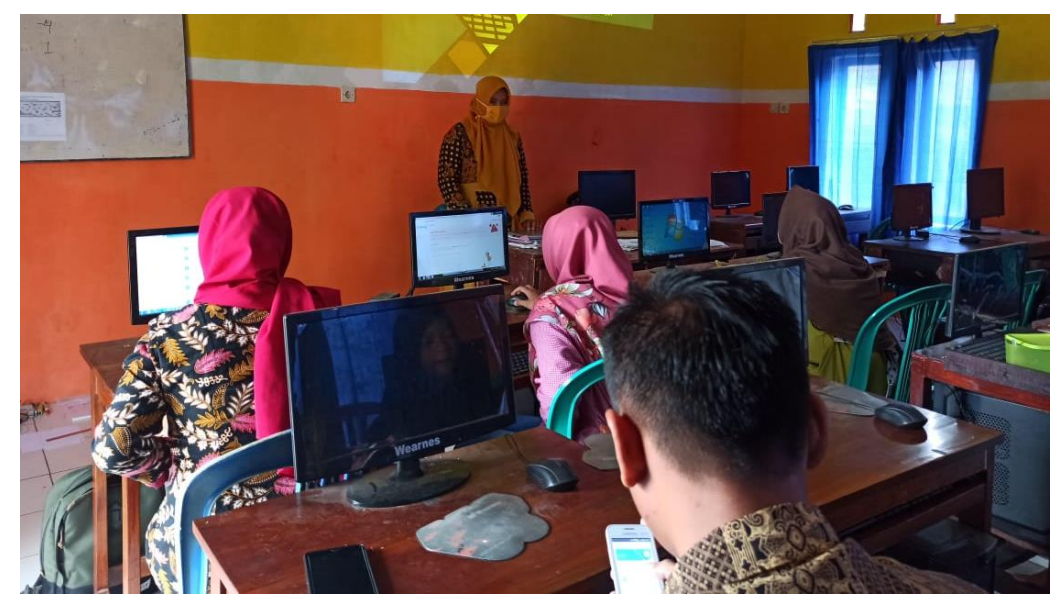

Gambar 4. Kegiatan pengabdian berupa sosialisasi yang dilakukan di SMP Mitra Jember 


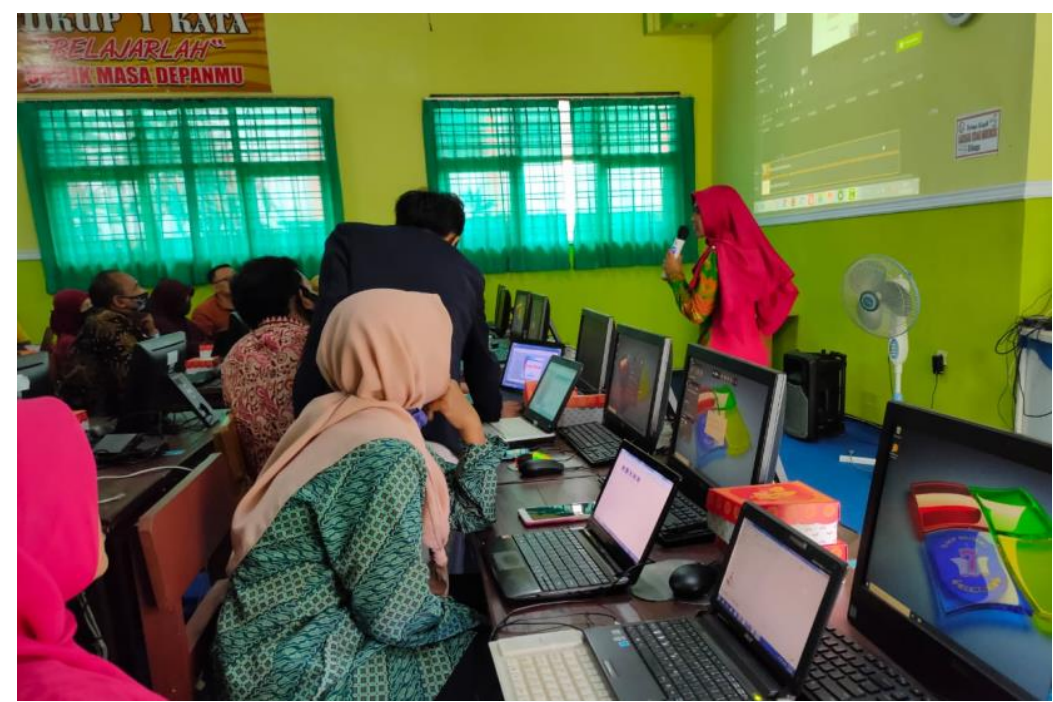

Gambar 5. Kegiatan pengabdian berupa Sosialisasi yang dilakukan di SMP Negeri 7 Jember

Pada akhir rangkaian kegiatan sosialisasi GESIT, peserta diminta untuk mengisi angket respon terhadap media GESIT yang telah dikembangkan. Angket respon terdiri dari 10 aspek penilaian untuk menggali informasi sejauh mana keefektifan penggunaan media GESIT. Selain itu, angket respon digunakan untuk mengetahui bagaimana pendapat guru terhadap media GESIT yang telah dikembangkan. Rekapitulasi angket respon peserta sosialisasi disajikan pada tabel 2.

Tabel 2. Rekapitulasi Angket Respon

\begin{tabular}{clcc}
\hline No & \multicolumn{1}{c}{ Aspek Penilaian } & Ya & Tidak \\
\hline 1 & Desain dan tampilan GESIT menarik & $80 \%$ & $20 \%$ \\
2 & GESIT mudah diunduh dan diinstall & $83 \%$ & $17 \%$ \\
3 & GESIT mudah digunakan & $78 \%$ & $22 \%$ \\
4 & GESIT menyajikan permasalahan Matematika & $90 \%$ & $10 \%$ \\
5 & GESIT memotivasi untuk belajar & $79 \%$ & $21 \%$ \\
6 & GESIT membantu mencapai kompetensi dasar & $77 \%$ & $23 \%$ \\
7 & GESIT menjadi media alternatif pada masa pandemi & $81 \%$ & $19 \%$ \\
8 & GESIT menjadi media alternatif pada pembelajaran & & \\
& daring & $83 \%$ & $17 \%$ \\
9 & GESIT menjadi referensi bagi guru untuk & $82 \%$ & $18 \%$ \\
& mengembangkan media sejenis & & \\
10 & GESIT memotivasi guru untuk mengembangkan media & $80 \%$ & $20 \%$ \\
\hline & berbasis android & $81 \%$ & $19 \%$ \\
\hline
\end{tabular}

Angket respon menunjukkan bahwa peserta sosialisasi memberikan respon positif terhadap media GESIT yang telah dikembangkan dengan tampilan dan gerakan karakter 
dalam tiga dimensi menambah daya tarik. GESIT mudah diunggah dan digunakan secara mandiri serta dapat digunakan secara offline. Bagi siswa yang gemar bermain game, GESIT dapat menjadi alternatif untuk bermain sambil belajar sehingga belajar lebih menyenangkan dan tidak menjemukan (Putra, dkk; 2016). GESIT dapat membantu siswa untuk belajar, khususnya pada materi pola bilangan. Hal tersebut sejalan dengan Arda, dkk (2015) yang menyimpulkan bahwa media pembelajaran interaktif dapat mendukung pemahaman konsep. GESIT juga diharapkan mampu meningkatkan kemampuan penalaran matematis disebabkan karena pemain dapat mengeksplore kemampuan guna menghadapi tantangan yang diberikan dalam setiap level. Hal tersebut sejalan dengan Vitianingsih (2016) bahwa game edukasi memiliki tantangan, ketepatan, daya nalar, dan etika. Selain itu, GESIT dapat membantu guru untuk menggunakan waktu seefisien mungkin (Karo-karo dan Rohani, 2018). Oleh karena itu, guru-guru merasa termotivasi untuk mengembangkan media serupa atau bahkan lebih dari itu guna menghadapi tantangan pembelajaran daring pada masa pandemi.

\section{SIMPULAN}

Proses pengembangan game edukasi menggunakan model Thiagarajan terdiri dari beberapa tahap. Tahapan-tahapan tersebut menghasilkan game edukasi yang valid berdasarkan uji validasi oleh ahli. Selain itu, GESIT praktis untuk digunakan dan efektif sebagai media pembelajaran alternatif pada masa pandemi COVID-19 berdasarkan angket respon positif dari siswa dan guru sebagai peserta sosialisasi. Tahap terakhir yaitu penyebaran dimana game edukasi "GESIT" dipublikasikan secara resmi di Google Playstore.

\section{UCAPAN TERIMAKASIH}

Penulis mengucapkan terimakasih kepada Universitas jember atas dukungan yang telah diberikan terhadap kegiatan pengabdian kepada masyarakat yang didanai oleh Hibah COVID-19 tahun 2020 sehingga kegiatan pengabdian dapat berjalan dengan lancar.

\section{DAFTAR PUSTAKA}

Arda, A., Saehana, S., \& Darsikin, D. (2015). Pengembangan Media Pembelajaran Interaktif Berbasis Komputer Untuk Siswa SMP Kelas VIII. Mitra Sains, 3(1), 69-77. Retrieved from http://mrtg.untad.ac.id/index.php/MitraSains/article/view/66. 
Firmansyah, D. (2015). Pengaruh Strategi Pembelajaran dan Minat Belajar Terhadap Hasil Belajar Matematika. Jurnal Pendidikan UNSIKA 3(1), 3-44. Retrieved from https://journal.unsika.ac.id/index.php/judika/article/view/199

Hasanah, dkk. (2020). Analisis Aktivitas Belajar Daring Mahasiswa Pada Pandemi COVID19. Jurnal Pendidikan 1(1).

Handarini, O I dan Wulandari, S S. (2020). Pembelajaran Daring sebagai Upaya Study from Home (SFH) selama Pandemi COVID-19. Jurnal Pendidikan Administrasi $\begin{array}{llll}\text { Perkantoran } & \text { (JPAP) } & \text { 8(3). } & \text { Retrieved }\end{array}$ https://journal.unesa.ac.id/index.php/jpap/article/view/8503/4094

Karo-karo, I R dan Rohani. (2018). Manfaat Media dalam Pembelajaran. AXIOM VII(1), 9196.

Martins, M. de L. (2015). How to Effectively Integrate Technology in the Foreign Language Classroom for Learning and Collaboration. Procedia - Social and Behavioral Sciences 174, 77-84. 10.1016/j.sbspro.2015.01.629

Nurrita, T. (2018). Pengembangan Media Pembelajaran untuk Meningkatkan Hasil Belajar Siswa. Misykat 3(01), 171-187. 10.33511/misykat.v3n1.171

Putra, D W, Nugroho A P, dan Puspitarini E W. (2016). Game Edukasi Berbasis Android sebagai Media Pembelajaran untuk Anak Usia Dini. JIMP - Jurnal Informatika Merdeka Pasuruan 1(1), 46-58. 10.37438/jimp.v1i1.7

Pratama, U N dan Haryanto. (2017). Pengembangan Game Edukasi Berbasis Android tentang Domain Teknologi Pendidikan. Jurnal Inovasi Teknologi Pendidikan. 4(2), 167-184. 10.21831/jitp.v4i2.12827

Vitianingsih, A V. (2016). Game Edukasi Sebagai Media Pembelajaran Pendidikan Anak Usia Dini. Jurnal INFORM 1(1), 1-8. 10.25139/ojsinf.v1i1.220 